\title{
Effect of Exhaust Gas Recirculation (EGR) on Performance and Emission of a Compression Ignition Engine with Staged Combustion (Insertion of Unburned Hydrocarbon)
}

\author{
Huss ain. $\mathbf{J}^{1, *}$, Palaniradja. $\mathrm{K}^{2}$, Alagumurthi. $\mathbf{N}^{2}$, Manimaran. $\mathbf{R}^{1}$ \\ ${ }^{1}$ Pondicherry Engineering College, Puducheery, India \\ ${ }^{2}$ Faculty of Mechanical Engineering, Pondicherry En gineering College, Puducheery, India
}

\begin{abstract}
The usage of EGR adopted diesel engine increasing day by day world wide to reduce the NOx emissions. The EGR adopted engines can reduce NOx Considerably but it adversely improves the emissions of UHC nearly 40 to $50 \%$. We can avoid this effect by Reutilization of UHC. In this paper the experimental investigation has been carried out on EGR adopted direct injection compression ignition engine with insertion of unburned hydro carbon rich exhaust. The results were presented and compared with all EGR levels. The result were evidenced that can reduce 20 to $25 \%$ of UHC by this method.
\end{abstract}

Keywords EGR, Engine Performance, Staged Combustion, Nox

\section{Introduction}

Better fuel economy and higher power with lower maintenance cost has increased the popularity of diesel engine vehicles. Diesel engines are used for bulk movement of goods, powering stationary/ mobile equipment, and to generate electricity more economically than any other device in this size range. In most of the global car markets, record diesel car sales have been observed in recent years[1]. The exhorting anticipation of additional improvements in diesel fuel and diesel vehicle sales in future have forced diesel engine manufacturers to upgrade the technology in terms of power, fuel economy and emissions. Diesel emissions are categorized as carcinogenic[2]. The stringent emission

leg is lations are compelling engine manufacturers to develop technologies to combat exhaust emissions. To meet these emission regulations with competitive fuel economy, exhaust gas after-treatment and optimized combustion are necessary. However, it is still unresolved which concept will succeed considering production and economic feasibility[3].

Diesel engines are very popular power plants for decentralized power production in rural areas all over the world as well as for powering the farm equipment due to their fuel economy, ease of maintenance and robustness. Diesel engines are assumed as a good alternative to gasoline

\footnotetext{
* Corresponding author:

shehussain2k6@yahoo.co.in (Hussain.J)

Published online at http//journal.sapub.org/ijee

Copyright (C) 2012 Scientific \& Academic Publishing. All Rights Reserved
}

engines because they produce lower amount of emissions[4]. On the other hand, higher emissions of oxides of nitrogen $\left(\mathrm{NO}_{\mathrm{x}}\right)$ and particulate matter $(\mathrm{PM})$ have been noticed as major problems. Although, major constituents of diesel exhaust include carbon dioxide $\left(\mathrm{CO}_{2}\right)$, water vapor $\left(\mathrm{H}_{2} \mathrm{O}\right)$, nitrogen $\left(\mathrm{N}_{2}\right)$, and oxygen $\left(\mathrm{O}_{2}\right)$; carbon monoxide $(\mathrm{CO})$, hydrocarbons (HC), oxides of nitrogen $\left(\mathrm{NO}_{\mathrm{x}}\right)$, and particulate matter (PM) are present in smaller but environmentally significant quantities. In modern diesel engines, first four species normally consist of mo re than $99 \%$ exhaust, while last four (the harmful pollutants) account for less than $1 \%$ exhaust [5]. $\mathrm{NO}_{\mathrm{x}}$ comprise of nitric oxide (NO) and nitrogen dioxide $\left(\mathrm{NO}_{2}\right)$ and both are considered to be deleterious to humans as well as environmental health. $\mathrm{NO}_{2}$ is considered to be more toxic than NO. It affects human health directly and is precursor to ozone formation, which is mainly responsible for smog formation. The ratio of NO2 and $\mathrm{NO}$ in diesel engine exhaust is quitesmall, but $\mathrm{NO}$ gets quickly oxidized in the environment, forming $\mathrm{NO}_{2}$ [6]. Since diesel engine mainly emits NO hence attention has been given to reduce the NO formation[7].

\subsection{Nox For mation Mechanism}

$\mathrm{NO}$ is formed inside the combustion chamber in post-flame combustion process in the high temperature region. The NO formation and decomposition inside the combustion chamber can be described by extended Zeldovich Mechanism[8]. The principal reactions at near stoichiometric fuel-air mixture governing the formation of NO from molecular nitrogen are 


$$
\begin{gathered}
\mathrm{O}+\mathrm{N}_{2}=\mathrm{NO}+\mathrm{N} \\
\mathrm{N}+\mathrm{O}_{2}=\mathrm{NO}+\mathrm{O} \\
\mathrm{N}+\mathrm{OH}=\mathrm{NO}+\mathrm{H}
\end{gathered}
$$

The initial rate controlled $\mathrm{NO}$ formation (i.e. when[NO]/[NO2] e_1) can be described by the Eq. (1). In the expression[NO] denotes the molar concentration of the species and[O2]e and[N2]e denotes the equilibrium concentration[7].

$\frac{d(N O)}{d x}=\frac{6 \times 10 e 16}{T^{0.5}} \exp \frac{-69,096}{d x T}\left\lceil 0210.5 t 0 e[N 2] e\right.$ mol s $/ \mathrm{cm}^{3}$

The sensitivity of NO formation rate to temperature and oxygen concentration is evident from this equation. Hence in order to reduce the NOx formation inside the combustion chamber, the temperature and oxygen concentration in the combustion chamber need to be reduced. Even though, certain cetane improving additives are capable of reducing NOx, the amount of reduction is reported to be inadequate. Moreover, most of these additives are expensive. Retarded injection is an effective method employed in diesel engines for $\mathrm{NO}_{\mathrm{x}}$ control. However, this method leads to increased fuel consumption, reduced power, increased $\mathrm{HC}$ emissions and smoke. Water injection is another method for $\mathrm{NO}_{\mathrm{x}}$ control however this method enhances corrosion of vital engine components.

In addition, it adds to the weight of the engine system because of requirement of a water storage tank. It is also difficult to retain water at a desired temperature during cold climate[9].

\subsection{Exhaust Gas Recirculation}

Exhaust Gas Recirculation is an effective method for NOx control. The exhaust gases mainly consist of carbon dioxide, nitrogen etc. and the mixture has higher specific heat compared to atmospheric air. Re-circulated exhaust gas displaces fresh air entering the combustion chamber with carbon dioxide and water vapor present in engine exhaust. As a consequence of this air displacement, lower amount of oxygen in the intake mixture is available for combustion. Reduced oxygen available for combustion lowers the effective air-fuel ratio. This effective reduction in air-fuel ratio affects exhaust emissions substantially. In addition, mixing of exhaust gases with intake air increases specific heat of intake mixture, which results in the reduction of flame temperature. Thus combination of lower oxygen quantity in the intake air and reduced flame temperature reduces rate of $\mathrm{NO}_{\mathrm{x}}$ formation reactions $[10,11]$. The EGR $(\%)$ is defined as the mass percent of the recirculated exhaust (MEGR) in the total intake mixture (Mi).

$$
\operatorname{EGR}(\%)=\frac{M E G R}{M i} \times 100
$$

Desantes et al. used NDIR-based $\mathrm{CO}_{2}$ concentration measurement at the intake $\left(\left[\mathrm{CO}_{2}\right]\right.$ int $)$ and exhaust manifold $\left(\left[\mathrm{CO}_{2}\right] \mathrm{exh}\right)$ for the determination of EGR rate[12].

$$
E G R=\frac{[\mathrm{co} 2] \mathrm{inl}-[\mathrm{co} 2] \mathrm{atm}}{[\mathrm{co} 2] \mathrm{exh}-[\mathrm{co} 2] \mathrm{atm}}
$$

The engines using EGR emit lower quantity of exhaust gases compared to non-EGR engines because part of the exhaust gas is re-circulated[13]. Thus even if the concentration of to xic substances in the exhaust gas remains unchanged, the total quantity of emission of toxic substances reduce for the same volu metric concentration. Dies el engines operating at low loads and generally tolerate a higher EGR ratio because re-circulating exhaust gases contain high concentration of oxygen and low concentration of carbon dioxide and water vapors. However at higher loads, the oxygen in exhaust gas becomes scarce and the inert constituents start dominating along with increased exhaust temperature. Thus, as load increases, diesel engines tend to generate more smoke because of reduced availability of oxygen[5]. Wagner et al. tried to achieve lower emission of NOx and soot using highly diluted intake mixture. At very high EGR rate (around 44\%), PM emission decreased sharply with a continuous drop in NOx emission but this high EGR rate significantly affect the fuel economy[14]. Sasaki et al. conducted experiments using EGR on direct injection gasoline engine and reported that an appropriate volume of EGR improves fuel economy and HC emissions. This phenomenon was presumably due to the intake temperature increase by EGR, which improved the flame propagation in the relatively lean region of the air-fuel mixture, which is non-uniformly distributed[15]. Kusaka et al. also found that at low loads, EGR combined with intake heating can favorably reduce $\mathrm{THC}$ emission with improvement in thermal efficiency[16]. EGR was also used in a direct injection spark ignition engine as an effective way for improving fuel economy[17,18]. Das et al. used EGR to reduce NOx emissions in hydrogen - supplemented SI engine without any undes irable co mbustion phenomena[19]. Sato et al. performed experiments using methanol in direct injection compression ignition engine and found that combustion performance becomes inferior under light load conditions because temperature in combustion chamber fell due to very high latent heat of methanol, thus hampering formation of combustible air-fuel mixture[20]. Selim et al. operated the diesel engine in dual fuel mode with natural gas and found inferior performance and emissions at low loads because lean mixtures formed at low loads were hard to ignite and had slow burning characteristics. EGR was found to be a method of improving engine performance and emissions of such engines[21]. However, application of EGR also leads to penalties. In case of diesel engines, these penalties include higher specific fuel consumption and particulate matter emissions. Effectively, a trade-off between NOx and soot is observed with the use of EGR[22-27]. The reduction in flame temperature reduces the rate of soot oxidation/re-burning. As a result, in EGR system, more soot is formed during combustion and it remains un-oxidized and eventually appears in the exhaust[10]. The rise in smoke (soot) level of engine exhaust due to EGR affects the engine performance in various ways. Increased soot level causes considerable increase in the carbon deposits and wear of the various vital engine parts such as cylinder liner, piston rings, valve train and bearings. Wear of the materials also increase due to chemical reactions taking place on the surface (adsorption, corrosion) or due to abrasion of material or 
rupture of anti-wear film by soot. The application of EGR also adversely affects the lubricating oil quality and engine durability[28-33]. Gautam et al. experimentally proved that soot interacts with oil additives reducing its anti-wear properties possibly by abrasive wear mechanis $\mathrm{m}$. Increased wear due to EGR is because of presence of soot in lubricating oil[29]. Studies on valve-train wear in presence of soot were performed by Nagai et al. As the EGR rate was varied from 0 to $17 \%$ to $25 \%$, the wear of cam noses and rocker arm tips was found to increase significantly[30]. If the exhaust gas is re-circulated directly to the intake, it results in increased intake charge temperature i.e. hot EGR. An increase in in let charge temperature always results in shorter ignition delay and may imp rove thermal efficiency[34]. If the exhaust gas is cooled before recirculation to combustion chamber, then it is called cooled EGR. Cooling of EGR increases the charge density therefore improves volumetric efficiency of the engine. Also, it provides additional benefits by lowering NOx emissions to a greater extent. However, condensation of moisture present in the exhaust increases corrosion in combustion chamber. Plee et al. reported that major influence on NOx emission is due to change in temperature rather than oxygen availability[35]. In the present study, EGR was implemented to see the effect of EGR on wear of piston rings. The piston rings are most vital parts between piston and cylinder. The engine was operated for $96 \mathrm{~h}$ in normal running conditions and the wear of the piston rings and deposits on vital engine parts were assessed. The engine was again operated for $96 \mathrm{~h}$ with EGR and similar observations were made for piston ring wear and deposits. Since, EGR results in more soot formation, which in-turn affects the lubricating oil by thickening the oil and increases the wear debris in lubricating oil. Increased soot level and wear debris in lubricating oil may adversely affect the piston rings because piston rings are used to scrap off the excess lubricating oil from the cylinder liner and return it to oil sump. Engine performance and carbon deposits on injector tip, cylinder head and piston crown were also investigated. Various emission legislations were tabulated in Table 1
Table 1. The European emission standards ( $\mathrm{g} / \mathrm{Km})$

$\begin{array}{cccccc}\text { Year } & \text { standard } & \text { CO } & \text { HC } & \text { Nox } & \text { PM } \\ 1996 & \text { Euro2 } & 4 & 1.1 & 7 & 0.15 \\ 2000 & \text { Euro3 } & 2.1 & 0.6 & 5 & 0.1 \\ 2005 & \text { Euro4 } & 1.5 & 0.46 & 3.5 & 0.02 \\ 2008 & \text { Euro5 } & 1.5 & 0.46 & 2 & 0.02 \\ 2013 & \text { Euro6* } & 1.5 & 0.13 & 0.4 & 0.01\end{array}$

* Proposed values Amar ibrahim et al-2010

\subsection{Specification of the Engine}

$\begin{array}{ll}\text { Engine Type } & : \text { 4Stroke Diesel } \\ \text { No of cylinders } & : 3 \\ \text { Combustion chamber } & : \text { Direct injection } \\ \text { Engine Displacement } & : 2826 \mathrm{cc} \\ \text { Bore X Stroke (mm) } & : 100 \times 120 \\ \text { Compression ratio } & : 17: 1 \\ \text { Max. Power } & : 52 \mathrm{HP} @ 2500 \mathrm{rpm} \\ \text { Max. Torque } & : 16.25 \mathrm{Nm} @ 1500 \mathrm{rpm} \\ \text { Valve mechanism } & : \text { SOHC }\end{array}$

\section{Experimental Setup and Methodology}

A two-cylinder constant speed diesel engine generator set was chosen to study the effect of EGR on the performance and emissions, carbon deposits, and wear of diesel engine components. The specifications of engine are given in section 2.1. The engine is coupled with an AC generator and the current generated is used by a resistive load bank, thus in-turn loading the engine. The generator is calibrated and all losses in the generator such as copper losses, armature current losses and friction and windage losses (unaccounted losses) are accounted for and taken into consideration while analysing the data. For recirculation of the exhaust gas, appropriate plumbing was done. No insulation on the pipe line was provided therefore allowing the re-circulated exhaust gases to partially cool down. the Exhaust gas drawn from the $1^{\text {st }}$ and $3^{\text {rd }}$ cylinder were partially allowed inside the $2^{\text {nd }}$ cylinder with the help of separate EGR control valve and the fuel supplied to the $2^{\text {nd }}$ cylinder was controlled by separate flow valve and corresponding fuel rate also considered for calculation The schematic diagram of the engine setup is shown in Fig. 1.

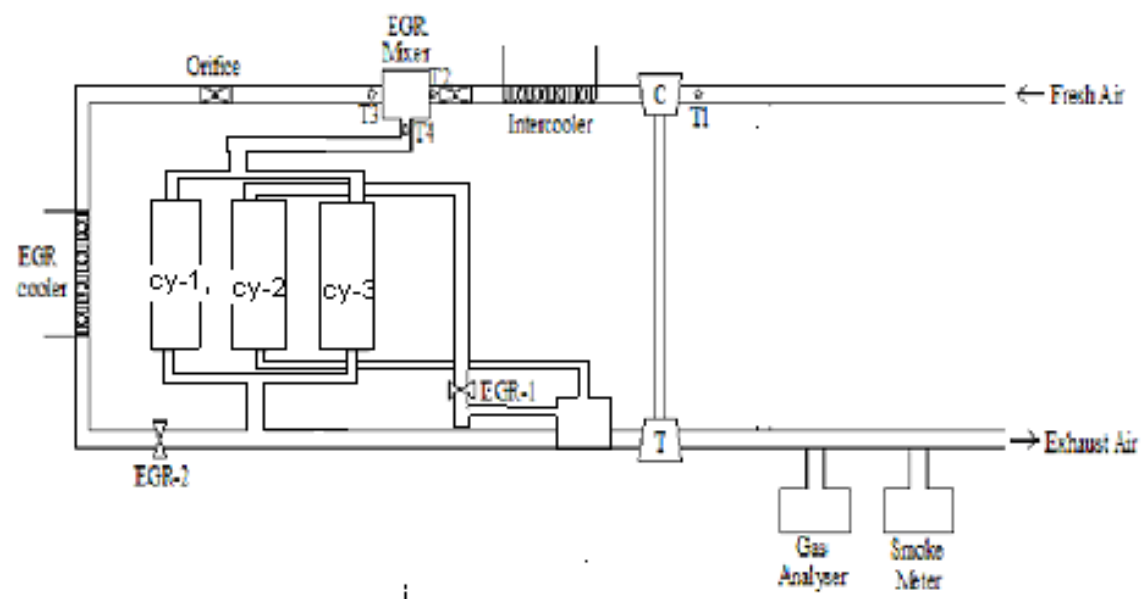

Figure 1. The schematic diagram of the engine setup 
The quantity of EGR can be regulated by a control valve installed in the EGR loop. An air box was provided in EGR loop to dampen the fluctuations of the pulsating exhaust. An orifice was installed in the EGR loop to measure the flow rate of re-circulated exhaust gas. To measure the intake air flow rate orifice meter was installed. Suitable instrumentation for measurement of temperatures at several locations was done. Fuel consumption measurement was done using a gravitational manometer. Exhaust gas emission measurements were done by raw exhaust gas emission analyser (Make: Horiba, Japan, Model: EXSA-1500). Oxygen, $\mathrm{CO}, \mathrm{NO}_{\mathrm{x}}$ and $\mathrm{CO}_{2}$ were measured by manual Orsat apparatus. The exhaust gas opacity was measured by a smoke opacity meter (Make: A VL, Austria, Model: 437). To achieve the objectives of the study, engine was run under normal operating condition and at different EGR rates. The data for $\mathrm{HC}, \mathrm{NO}_{\mathrm{x}}, \mathrm{CO}$, smoke opacity, exhaust gas temperature, and fuel consumption were recorded. Then, engine performance and emission patterns were compared. Optimum EGR rate was found on the bas is of performance and emissions of the engine. Then, the engine was run with and without EGR and also with staged combustion for total $6 \mathrm{~h}$ in each phase separately using a fixed test cycle shown in Table 2.

Table 2. Engine test cycle for endurance test

Load Duration (min)

$\begin{array}{lc}\text { No load } & 20 \\ 100 \% \text { load } & 30 \\ 50 \% \text { load } & 120 \\ \text { No load } & 20 \\ 75 \% \text { load } & 60 \\ \text { No load } & 20 \\ \text { 100\% load } & 30 \\ 75 \% \text { load } & 60 \\ \quad \text { Total } & 360(6 \mathrm{~h})\end{array}$

\section{Results and Discussion}

The engine was run on different loads at $1500 \mathrm{rpm}$ with different EGR rates (from $0 \%$ to $25 \%$ ) to investigate the effect of EGR on engine performance and emissions. The performance and emission data was analysed and presented graphically for thermal efficiency, BSFC, exhaust gas temperature, $\mathrm{HC}, \mathrm{CO}$, NOx emission, and smoke opacity.

\subsection{Engine Perfor mance Analysis}

The trends of thermal efficiency are shown in Fig. 2. Thermal efficiency is found to have slightly increased with EGR at lower engine loads. The possible reason may be re-burning of hydrocarbons that enter the combustion chamber with the re-circulated exhaust gas. At part loads, exhaust gas has less $\mathrm{CO}_{2}$ and fairly high amount of $\mathrm{O}_{2}$. Also, partly-cooled EGR acts like a pre-heater of the intake mixture. When this exhaust gas is re-circulated in the cylinder, the unburned $\mathrm{HC}$ in exhaust gas burns because of sufficient $\mathrm{O}_{2}$ available in combustion chamber and reasonably high intake temperatures. In staged combustion excess of unburned hydrocarbons utilized with reduced fuelling rates at higher engine loads, the thermal efficiency re mains unaffected by EGR. At higher loads, exhaust gas has higher amount of $\mathrm{CO}_{2}$, which reduces maximu m temperature in combustion chamber along with oxygen availability therefore re-burning of $\mathrm{HC}$ is not significant.
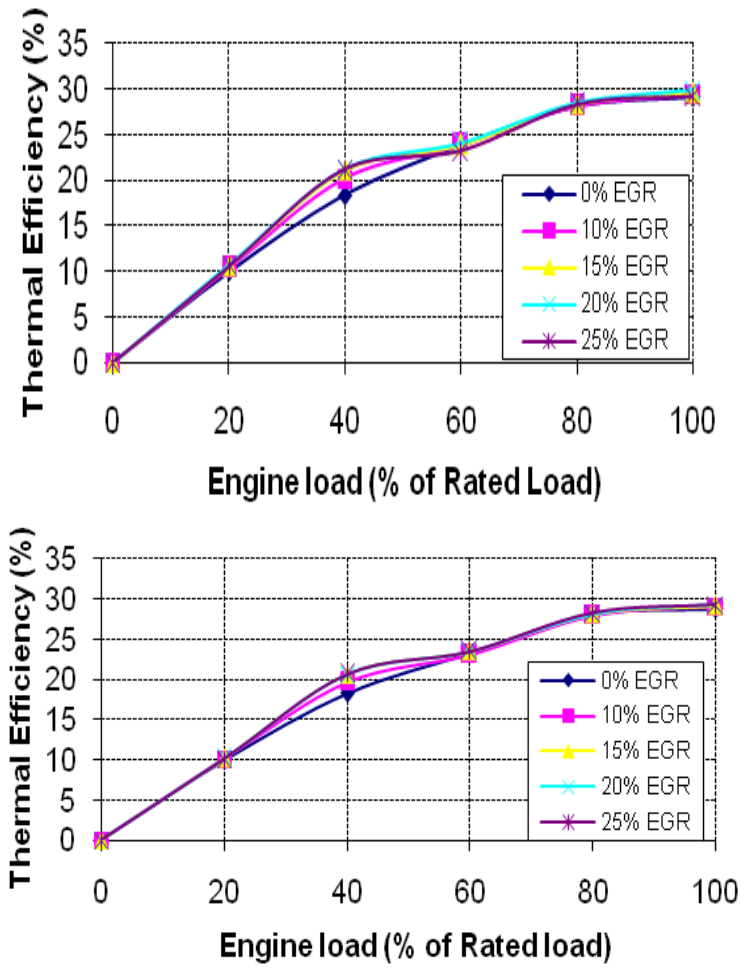

Figure 2. Thermal Efficiency for Different EGR Rates,a).EGR Without Staged Combustion, b) EGR W ith Staged Combustion

Fig. 3 represents comparison of BSFC for all datasets using EGR with baseline data. BSFC is lower at lower loads for engine operated with EGR compared to without EGR. However, at higher engine loads, BSFC with EGR is almost similar to that of without EGR. At higher loads, amount of fuel supplied to the cylinder is increased at higher rate and oxygen available for combustion gets reduced. Thus, air fuel ratio is changed and this increases the BSFC. In staged combustion the fuel was burned with Exhaust hence it further reduces the BSFC.

The exhaust gas temperatures are shown in Fig. 4. It has been observed that with increase in load, exhaust gas temperature also increases. When the engine is operated with partly-cooled EGR, the temperature of exhaust gas is generally lower than temperature of exhaust gas at normal operating condition. Exhaust gas temperature decreases with increase in EGR rate. The reasons for temperature reduction are relatively lower availability of oxygen for combustion and higher specific heat of intake air mixture as explained 
earlier. In staged combustion the recirculated exhaust was entered in the $2^{\text {nd }}$ cylinder, moreover it further reduces the temperature of exhaust.
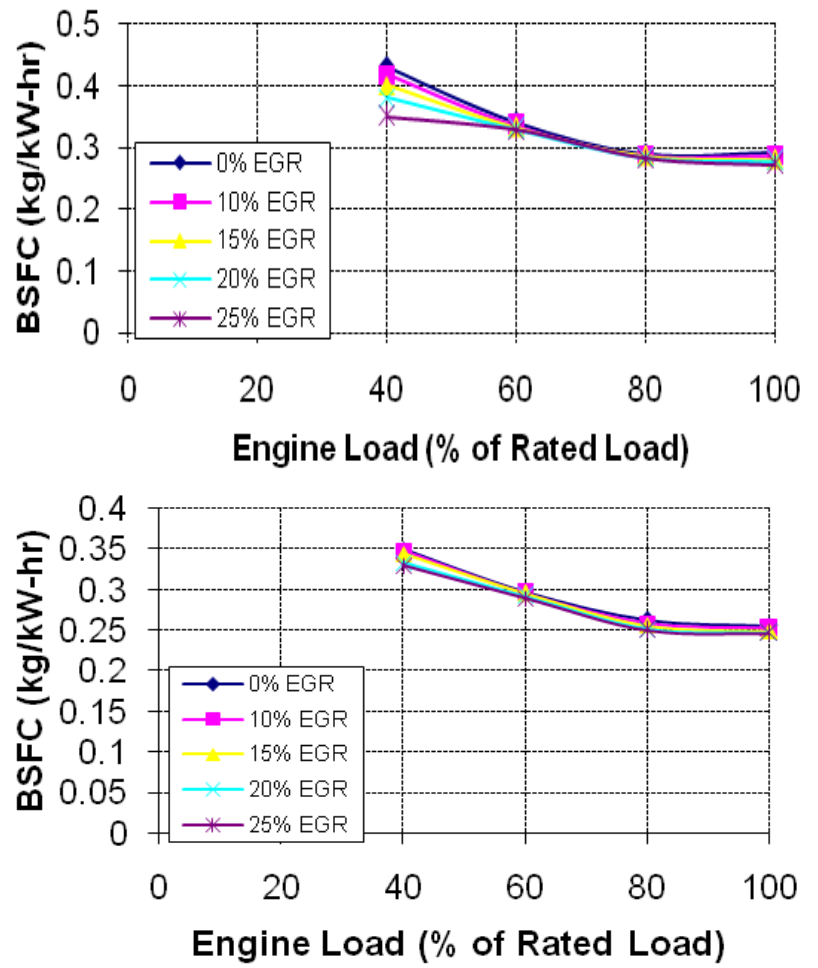

Figure 3. Brake Specific Fuel Consumption for different EGR Rates,a).EGR Without Staged Combustion b) EGR With Staged Combustion
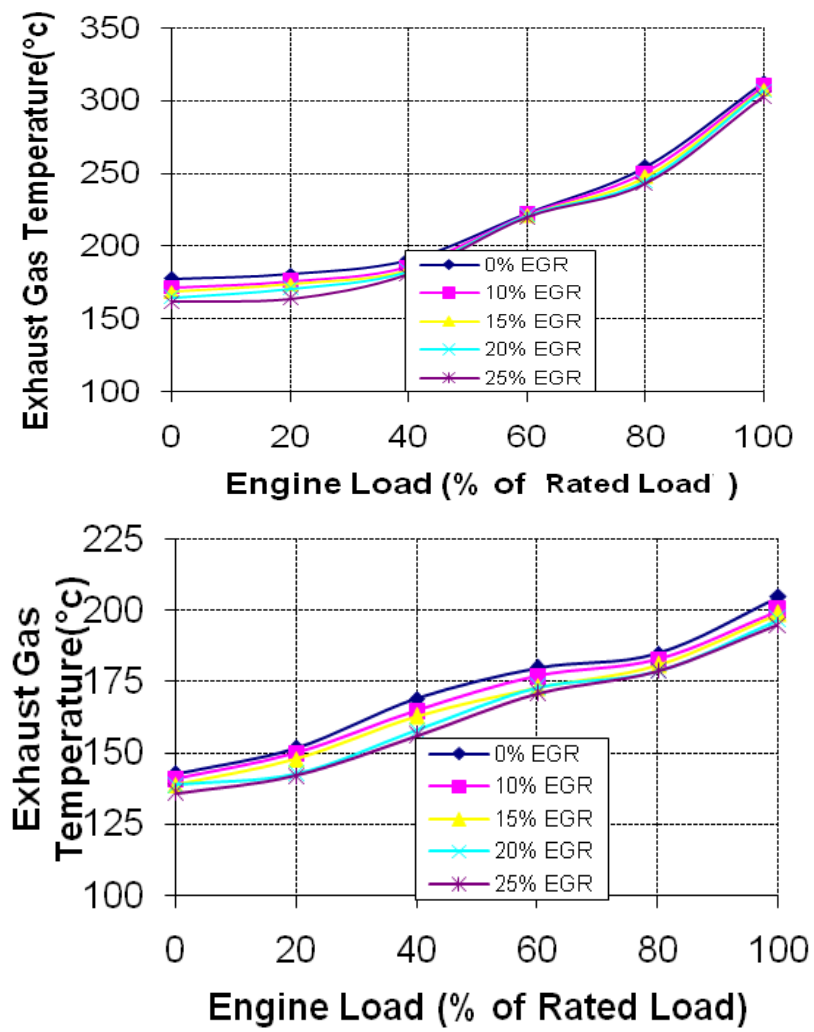

Figure 4. Exhaust Gas Temperatures for various EGR rates, a).EGR W ithout Staged Combustion b) EGR With Staged Combustion
Fig. 5 represents the variation of exhaust gas temperature at the entry to the inlet manifold for different EGR flow rates. These graphs show that exhaust gas temperature at entry to inlet manifold is not very high because exhaust gases are partly cooled before mixing with fresh air at atmospheric temperature. At part loads, this temperature at various EGR rates is close to atmospheric temperature. However, when load and EGR rates are increased, the exhaust temperature at the entry to the inlet manifold becomes higher than atmospheric temperature and therefore EGR acts as a pre-heater to fresh intake air but in case of staged combustion the inlet manifold temperature were observed higher compared to EGR because of the reason of the raw exhaust drawn from the cylinder was directly introduced in to the $2^{\text {nd }}$ cylinder
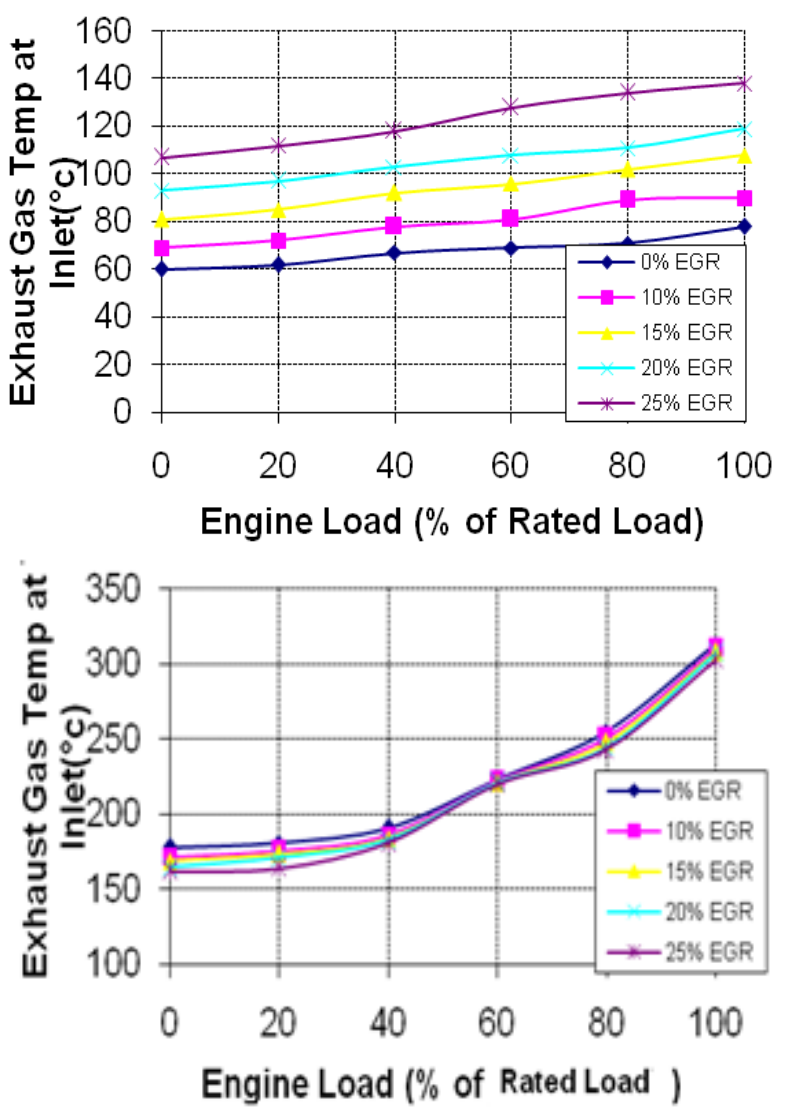

Figure 5. Exhaust Gas Temperature at the entry of inlet manifold for various EGR Rates, a).EGR Without Staged Combustion b) EGR With Staged Combustion

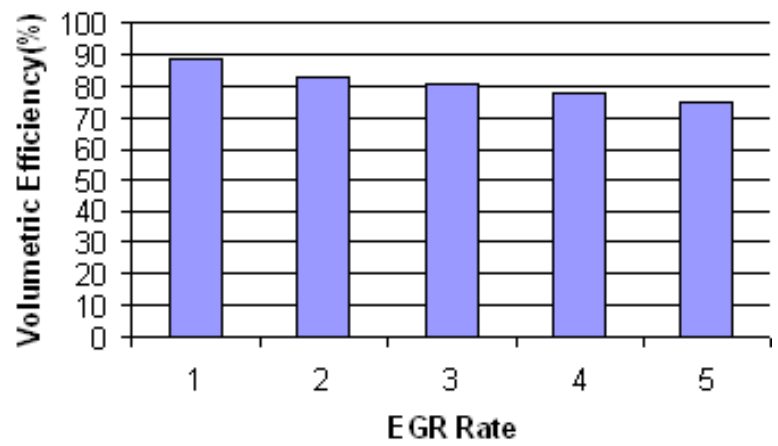

Figure 6. Volumetric Efficiency for different EGR Rates 
Fig. 6 represents volumetric efficiency for different EGR rates. It can be seen that as the EGR rate is increased, volumetric efficiency decreases. The intake air mass flow reduces because of EGR implementation and this means the volumetric efficiency drops. Ghazikhanietal et al. also found that volumetric efficiency drops when EGR rate is increased[36].

\subsection{Engine Emission Analysis}

Effect of EGR on unburned hydrocarbon (HC) and carbon monoxide (CO) are shown in Figs. 7 and 8, respectively. These graphs show that $\mathrm{HC}$ and $\mathrm{CO}$ emissions increase with increasing EGR. Lower excess oxygen concentration results in rich air-fuel mixtures at different locations inside the combustion chamber. This heterogeneous mixture does not combust completely and results in higher hydrocarbons, and carbon monoxide emissions. At part loads, lean mixtures are harder to ignite because of heterogeneous mixture and produce higher a mount of $\mathrm{HC}$ and $\mathrm{CO}$. Fig. 9 shows the ma in benefit of EGR in reducing NOx emissions from diesel engine. The degree of reduction in NOx at higher loads is higher. The reasons for reduction in $\mathrm{NO}_{\mathrm{x}}$ emissions using EGR in diesel engines are reduced oxygen concentration and decreased flame temperatures in the combustible mixture. At the part load, $\mathrm{O}_{2}$ is available in sufficient quantity but at high loads, $\mathrm{O}_{2}$ reduces drastically, there fore $\mathrm{NOx}$ is reduced more at higher loads compared to part loads.
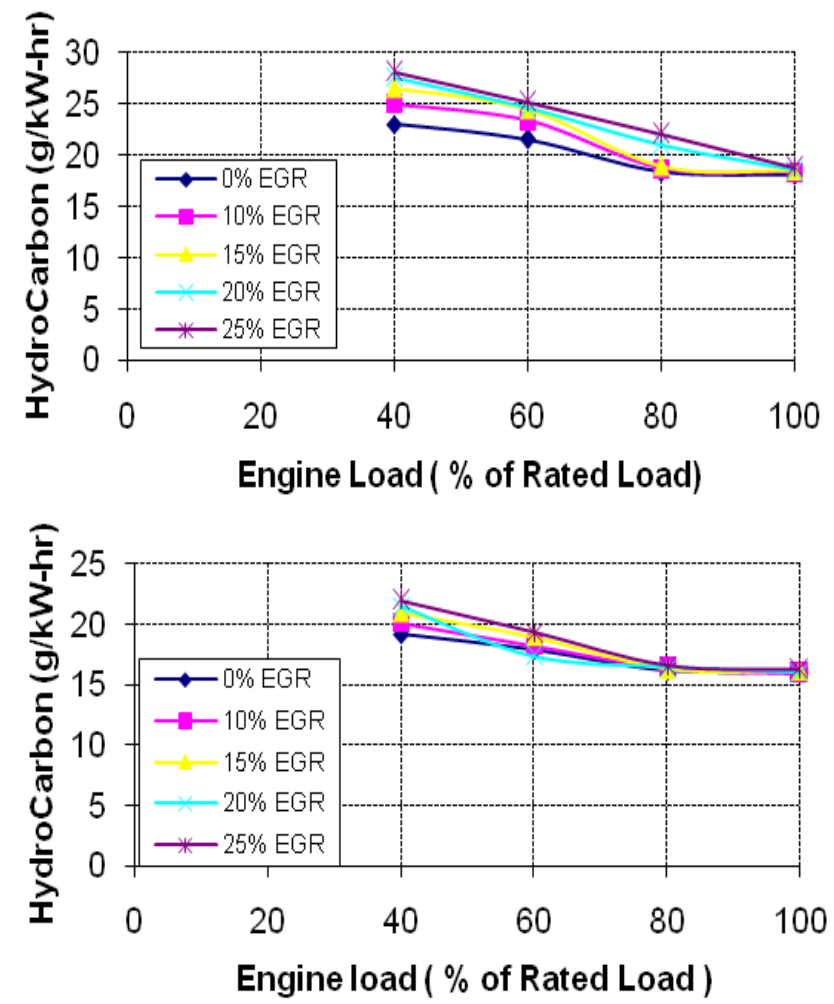

Figure 7. Hydro Carbons for different EGR Rates, a).EGR W it hout Staged Combustion, b) EGR With Staged Combustion
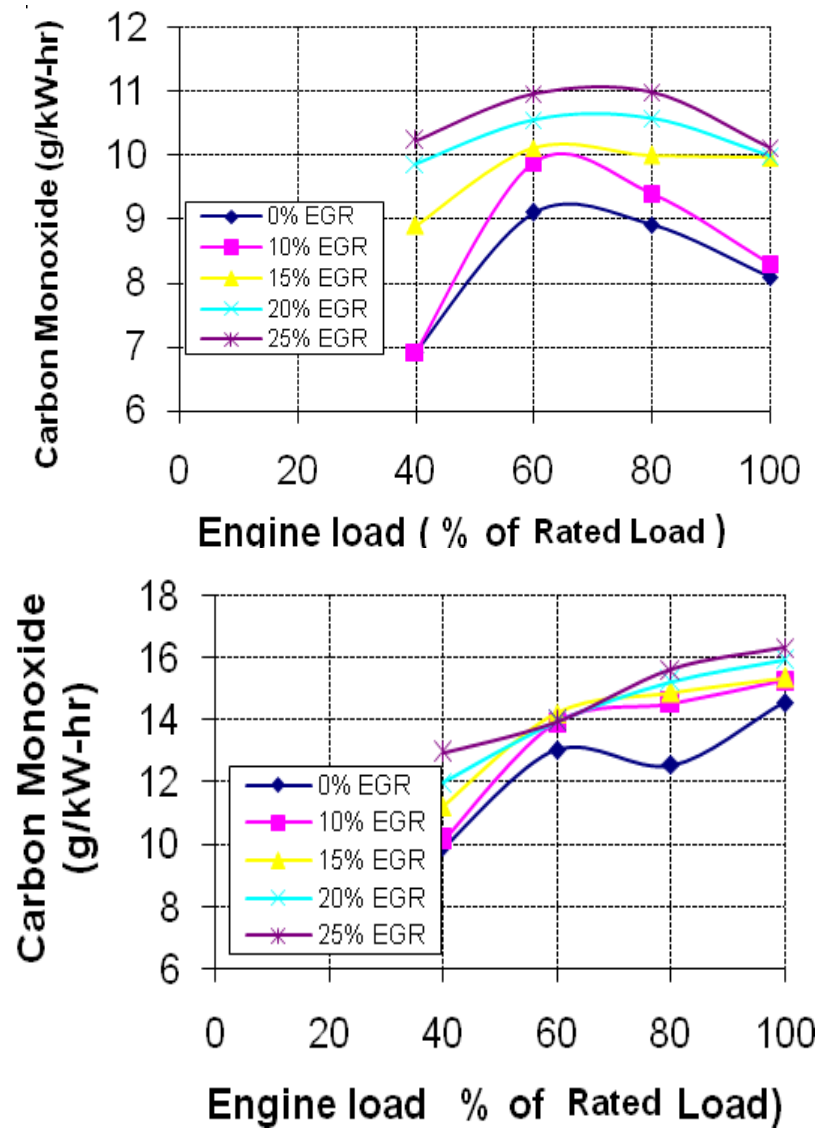

Figure 8. Carbon Monoxide for different EGR Rates, a).EGR Without Staged Combustion, b) EGR With Staged Combustion
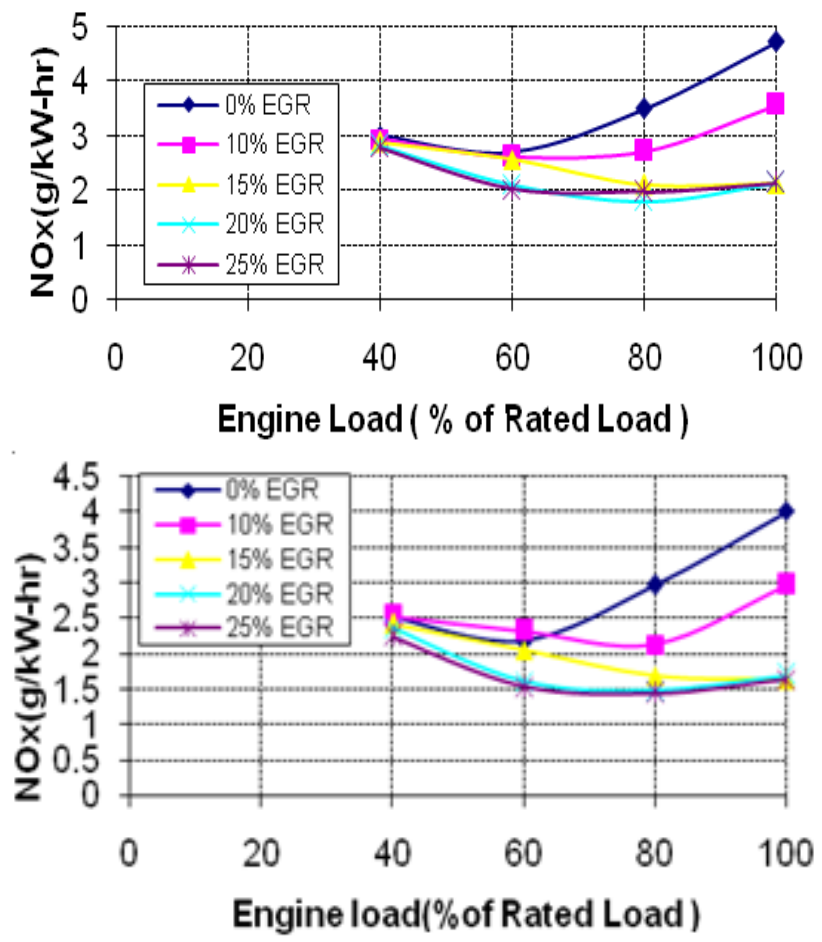

Figure 9. NOx for different EGR Rates, a).EGR Without Staged Combustion , b) EGR With Staged Combustion 
The smoke opacity of the exhaust gas is measured to quantify the particulate matter present in the exhaust gas. The smoke opacity is shown in Fig. 10. Higher smoke opacity of the exhaust is observed when the engine is operated with EGR compared to without EGR. The variation in the s moke opacity level at high loads was higher co mpared to that at lower loads. EGR reduces availability of o xygen for combustion of fuel, which results in relatively incomplete combustion and increased formation of particulate matter. EGR system is significantly more than that of engine operated without EGR. The higher carbon deposits in the EGR system seem to be because of higher soot formation. These pictures support the results obtained by smoke opacity (Fig. 10).
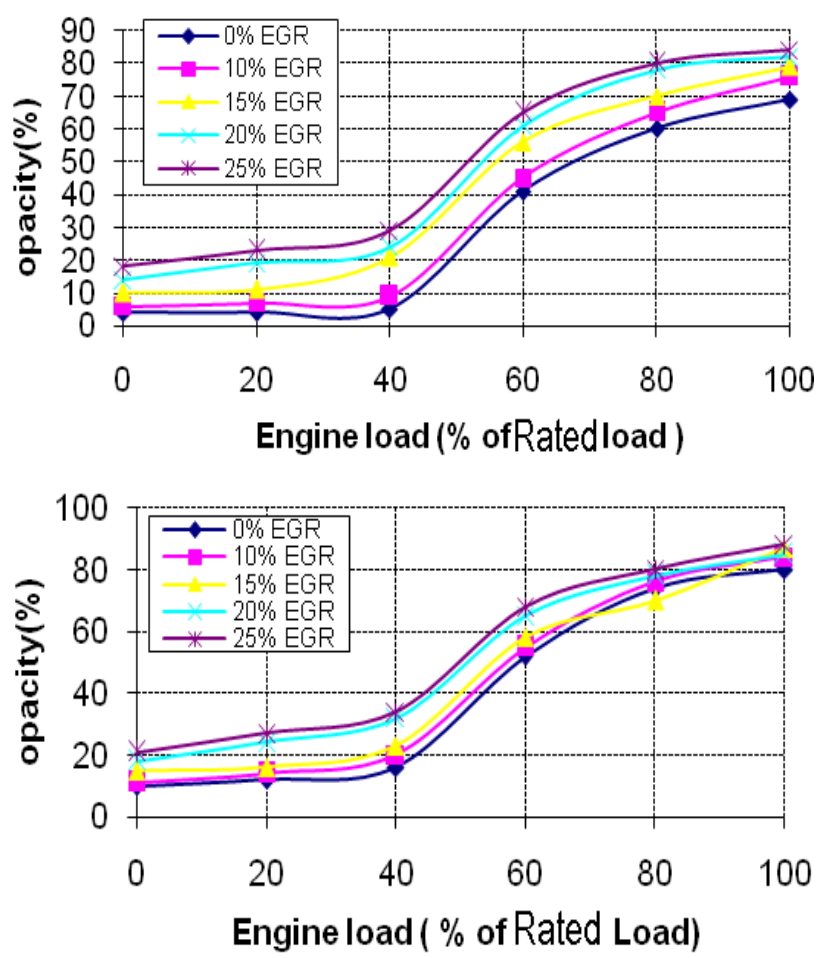

Figure 10. Smoke Opacity for different EGR rates, a).EGR Without Staged Combustion , b) EGR With Staged Combustion

\section{Conclusions}

In the present research, experimental investigations were conducted to study the effect of EGR with and without staged combustion on performance and emissions of a diesel engine. EGR displaces oxygen in the intake air by exhaust gas re-circulated to the combustion chamber. Reduced oxygen and lower flame temperatures affect performance and emissions of diesel engine in different ways. Thermal efficiency is slightly increased and BSFC is decreased at lower loads with EGR compared to without EGR. But at higher loads, thermal effic iency and BSFC are almost similar with EGR than without EGR. Exhaust gas temperature is decreased with EGR. Hydrocarbons, carbon monoxide, and smoke opacity are increased with EGR, but NOx emission decreases significantly. It can be observed that 15\% EGR rate is found to be effective to reduce NOx emission substantially without deteriorating engine performance in terms of thermal efficiency, SFC, and emissions. At lower loads, EGR reduces

NOx without deteriorating performance and emissions at higher levels. At higher loads, increas ed rate of EGR reduces NOx to a great extent but deteriorates performance and emis sions. Thus, it can be concluded that higher rate of EGR can be applied at lower loads. EGR can be applied to diesel engine without sacrificing its efficiency and fuel economy and NOx reduction can thus be achieved.

\section{ACKNOWLEDGEMENTS}

We wish to express our appreciation to Pondicherry Engineering College for supporting the project under which the current investigation has been conducted. Also we wish to express our gratitude to our guide for providing experimental data for this investigation and the guidelines during the coordination of the experiment

\section{REFERENCES}

[1] Annual dies el report. $<$ http://www.ricardo.com/pages/dieselr eport.asp $>$.

[2] Stewart KM. Health effects of diesel exhaust. Report from American Lung Association of Pennsylvania; 2001.

[3] Moser FX, Sams T, Cartellieri W. Impact of future exhaust gas emission legislation on the heavy duty truck engine. JSAE 2001-01-0186; 2001.

[4] Walsh MP. Global diesel emission trends. Automotive Eng Int 1998:114-8.

[5] Zheng M, Reader GT, Hawley JG. Diesel engine exhaust gas recirculation - a review on advanced and novel concept. Energy Convers Manage 2004;45:883-900.

[6] Pipho MJ, Kittelson DB, Zarling DD. NO2 formation in a diesel en gine. JSAE 910231; 1991.

[7] Levendis YA, Pavlatos I, Abrams R. Control of diesel soot, hydrocarbon and NOx emissions with a particulate trap and EGR. SAE 940460; 1994.

[8] Heywood JB. Internal combustion engines fundamentals. International ed. New-York: Mc-Graw Hill; 1988.

[9] Pradeep V, Sharma RP. Use of hot EGR for NOx control in a compression ignition engine fuelled with bio-diesel from Jatropha Oil. Renew Energy 2007;32(7):1136-54.

[10] Ladommatos N, Balian R, Horrocks R, Cooper L. The effect of exhaust gas recirculation on soot formation in a high-speed direct-injection diesel en gine. SAE 960841; 1996.

[11] Abd-Alla GH. Using exhaust gas recirculation in internal combustion engines: a review. Energy Convers Manage 2002;43:1027-42.

[12] Desantes JM, Galindo J, Guardiola C, Dolz V. Air mass flow estimation in turbocharged diesel engine from in-cylinder pressure measurement. Exp Therm Fluid Sci 2010;34:37-47. 
[13] Stumpp G, Banzhaf W. An exhaust gas recirculation system for diesel en gines. SAE 780222; 1978 .

[14] Wagner RM, Green Jr JB, Dam TQ, Edwards KD, Storey JM. Simultaneous low engine-out NOx and particulate matter with highly diluted diesel combustion. SAE 2003-01-0262; 2003.

[15] Sasaki S, Sawada D, Ueda T, Sami H. Effect of EGR on direct injection gasoline en gine. JSAE Rev 1998;19:223-8.

[16] Kusaka J, Okamoto T, Daisho Y, Kihara R, Saito T. Combustion and exhaust gas emission characteristics of a diesel engine dual-fueled with natural gas. JSAE Rev 2000;21:489-96.

[17] Bai Y-L, Wang Z, Wang J-X. Part load characteristics of direct injection spark ignition en gine using exhaust gas trap. Appl Energy 2010;87: 2640-6.

[18] Fontana G, Galloni E. Experimental analysis of a spark ignition engine using exhaust gas recycle at WOT operation. Appl Energy 2010;87:2187-93.

[19] Das LM, Mathur R. Exhaust gas recirculation for NOx control in a multi cylinder hydrogen supplemented S.I. engine. Int J Hydrogen Energy 1993;18(12): 1013-8.

[20] Sato Y, Noda A, Sakamoto T. Combustion control of direct injection methanol engine using a combination of charge heating and exhaust gas recirculation. JSAE Rev 1995;16:369-73.

[21] Selim MYE. Effect of exhaust gas recirculation on some combustion characteristics of dual fuel engine. Energy Convers Manage 2003;44: 707-21.

[22] Wade RW. Light duty NOx-HC particulate trade-off. SAE No. $800335 ; 1980$.

[23] Needham JR, Doyle DM, Nicol AJ. The low NOx truck engine. SAE No. 910731; 1991

[24] Agarwal AK, Singh SK, Sinha S, Shukla MK. Effect of EGR on the exhaust gas temperature and exhaust opacity in compression ignition en gines. Sadhana 2004;29:275-84.

[25] Mehta S, Oey F, Sumbung CL, Levendis YA. An aerodynamically regenerated diesel particulate trap with a flow-through soot incinerator section. JSAE 940461; 1994.

[26] Cinar C, Topgul T, Ciniviz M, Hasimoglu C. Effects of injection pressure and intake $\mathrm{CO} 2$ concentration on performance and emission parameters of an IDI turbocharged diesel en gine. Appl Therm Eng 2005;25:1854-62.

[27] Dec JE. Advanced compression ignition enginesunderstanding the in-cylinder processes. Proc Combust Inst 2009;32:2727-42.

[28] Ishiki K, Oshida S, Takigu chi M. A study of abnormal wear in power cylinder of diesel en gine with EGR-wear mechanism of soot contaminated in lubricating oil. SAE 2000-01-0925; 2000 .

[29] Gautam M, Chitoor K, Durbha M, Summers JC. Effects of diesel soot contaminated oil on engine wear-investigation of Noval oil formulations. Tribol Int 1999;32:687-99.

[30] Nagai I, Endo H, Nakamura H, Yano H. Soot and valve train wear I passenger car diesel en gines. SAE 831757; 1983.

[31] Aldajah A, Ajayi OO, Fenske GR, Goldblatt IL. Effect of exhaust gas recirculation (EGR) contamination of diesel engine oil on wear. Wear 2007;263:93-8.

[32] George S, Balla S, Gautam M. Effect of diesel soot contaminated oil on engine wear. Wear 2007;262:1113-22.

[33] Singh SK, Agarwal AK, Sharma M. Experimental investigations of heavy metal addition in lubricating oil and soot deposition in an EGR operated engine. Appl Therm Eng 2006;26:259-66.

[34] Ladommatos N, Balian R, Horrocks R, Cooper L. The effect of exhaust gas recirculation on combustion and $\mathrm{NOx}$ emissions in a high-speed directinjection diesel engine. SAE 960840; 1996.

[35] Plee SL, Ahmad T, Myers JP, Faeth GM. Diesel NOx emissions - a simple correlation technique for intake air effects. In: 19th Int symp on combustion. The Combustion Institute; 1982. p. 1495-502.

[36] Ghazikhani M, Feyz ME, Joharchi A. Experimental investigation of the exhaust gas recirculation effects on irreversibility and brake specific fuel consumption of indirect injection diesel engines. Appl Therm Eng 2010;30:1711- 